\title{
PENGARUH GAYA KEPEMIMPINAN PARTISIPATIF DAN KOMUNIKASI ORGANISASI TERHADAP KINERJA KARYAWAN MELALUI KEPUASAN KERJA SEBAGAI VARIABEL INTERVENING
}

\author{
Muhammad Nur Rokib; Djoko Santoso \\ mnrokib5@gmail.com.
}

djoko_hw@usm.ac.id

Magister Manajemen, Universitas Semarang, Semarang, Indonesia

\section{Info Artikel}

Sejarah Artikel: Diterima

Disetujui

Dipublikasikan

\section{Keywords:}

participatory

leadership style;

organizational

communication;

job satisfaction;

employee

performance

\section{Abstrak}

Penelitian ini bertujuan untuk mengetahui pengaruh gaya kepemimpinan partisipatif, komunikasi organisasi terhadap kinerja karyawan melalui kepuasan kerja sebagai variabel intervening.

Responden yang digunakan adalah 50 karyawan pada Kantor Jasa Penulai Publik Jimmy Prasetyo \& Rekan. Data penelitian dikumpulkan dengan menggunakan kuesioner. Analisis data dilakukan dengan menggunakan Teknik Analisis Regresi Berganda, dan analisis jalur.

Berdasarkan hasil penelitian diketahui bahwa (1) gaya kepemimpinan partisipatif berpengaruh positif dan signifikan terhadap kepuasan kerja karyawan pada KJPP Jimmy Prasetyo \& Rekan (2) Komunikasi organisasi berpengaruh positif dan signifikan terhadap kepuasan kerja karyawan pada KJPP Jimmy Prasetyo \& Rekan (3) kepuasan kerja berpengaruh positif dan signifikan terhadap kinerja karyawan pada KJPP Jimmy Prasetyo \& Rekan (4) gaya kepemimpinan partisipatif berpengaruh positif dan signifikan terhadap kinerja karyawan pada KJPP Jimmy Prasetyo \& Rekan (5) komunikasi organisasi berpengaruh positif dan signifikan terhadap kinerja karyawan pada KJPP Jimmy Prasetyo \& Rekan.

\section{THE EFFECT OF PARTICIPATIVE LEADERSHIP STYLE AND ORGANIZATIONAL COMMUNICATION ON EMPLOYEES PERFORMANCE THROUGH WORKING SATISFACTION AS INTERVENING VARIABEL}

\begin{abstract}
This study aims to determine the effect of participatory leadership style, organizational communication on employee performance through job satisfaction as an intervening variable.

The respondents used were 50 employees at the Public Starter Services Office Jimmy Prasetyo \& Partners. Research data was collected using a questionnaire. Data analysis was performed using Multiple Regression Analysis Techniques, and path analysis.

Based on the results of the study it is known that (1) participatory leadership style has a positive and significant effect on employee job satisfaction at KJPP Jimmy Prasetyo \& Partners (2) Organizational communication has a positive and significant effect on employee job satisfaction at KJPP Jimmy Prasetyo \& Rekan (3) job satisfaction has a positive and significant effect on employee performance on KJPP Jimmy Prasetyo \& Rekan (4) participatory leadership style has a positive and significant effect on employee performance on KJPP Jimmy Prasetyo \& Rekan (5) organizational communication has a positive and significant effect on the performance of employees at KJPP Jimmy Prasetyo \& Partners..
\end{abstract}

\footnotetext{
Alamat korespondensi : Jl Soekarno-Hatta, Semarang
}

E-mail:mnrokib5@gmail.com. 


\section{PENDAHULUAN}

Sumber daya manusia merupakan aset paling penting dalam suatu organisasi karena merupakan sumber daya yang mengarahkan organisasi serta mempertahankan dan mengembangkan organisasi dalam berbagai tuntutan masyarakat dan jaman. Oleh karena itu, sumber daya manusia harus selalu diperhatikan, dijaga dan dikembangkan. Suatu badan organisasi yang diharapkan dapat menunjukkan eksistensinya dalam hal positif artinya mampu menunjukkan kinerja yang baik. Kinerja adalah hasil yang dicapai seseorang menurut ukuran yang berlaku untuk pekerjaan yang bersangkutan. Kinerja pada dasarnya adalah apa yang dilakukan atau tidak dilakukan karyawan. Kurangnya kinerja yang ditunjukkan karyawan dapat mengancam kelangsungan suatu perusahaan, karena target yang telah ditetapkan tidak dapat tercapai.

Individu yang memiliki kinerja baik akan menunjukkan kuantitas dan kualitas dalam melaksanakan tugasnya sesuai dengan tanggung jawab yang diberikan kepadanya (Mangkunegara, 2007). Karyawan diharapkan dapat menunjukkan kinerja yang maksimal, sehingga tujuan utama dari organisasi dapat tercapai. Pencapaian kinerja maksimal juga merupakan target dari Kantor Jasa Penilai Publik (selanjutnya disingkat KJPP) Jimmy Prasetyo \& Rekan dahulu PT. Sapta Sentra Jasa Pradana) di tengahtengah kondisi persaingan jasa penilai publik di Indonesia.

KJPP Jimmy Prasetyo \& Rekan merupakan perusahaan yang bergerak di bidang jasa penilaian yang didukung oleh tenaga-tenaga profesional yang sudah berpengalaman dan mempunyai integritas yang tinggi dalam bidang penilaian. KJPP Jimmy Prasetyo \& Rekan merupakan salah satu kantor jasa penilai dari Kumpulan Kantor Jasa Penilai yang berada di Indonesia sebanyak 119 KJPP (Kementrian Keuangan Per 31 Desember 2016).

KJPP Jimmy Prasetyo \& Rekan didirikan pada tanggal 05 Juni 2007, berdasarkan Akta Pendirian Perusahaan Nomor 05 oleh Notaris Leolin Jayayanti S.H.dan telah dicatatkan di Pengadilan Negeri Jakarta Pusat. Terdapat beberapa jasa penilaian yang ditawarkan oleh KJPP Jimmy Prasetyo \& Rekan, antara lain:

1. Jasa Penilaian

Penilaian meliputi properti mencakup antara lain tanah, bangunan-bangunan perumahan, kantor, pertokoan, hotel, industri beserta sarana pelengkap lainnya, perlengkapan bangunan, perabot dan peralatan kantor dan hotel, mesin-mesin dan peralatan, alat-alat berat, kendaraan bermotor, pesawat udara, kapal laut, dan lainlain, kehutanan, perkebunan dan pertambangan.

2. Jasa Konsultasi

Pelayanan jasa konsultasi dalam hal-hal studi kelayakan, studi pasar, dan pengembangan property.

3. Jasa Pengawasan Pembiayaan Proyek

Meliputi kompleks perumahan, apartemen dan townhouse, perkantoran, pertokoan, bangunan komersial lainnya, pertambangan, perkebunan, kehutanan, dan bangunan kapal.

Mangkunegara (2007) menyatakan bahwa kinerja merupakan hasil dari beberapa faktor, salah satunya adalah faktor dukungan organisasi, yang memberikan kesempatan untuk berbuat sesuatu. Dukungan organisasi meliputi kepemimpinan. Wibowo (2013) menyatakan bahwa kepemimpinan pada hakikatnya adalah kemampuan individu dengan menggunakan kekuasaannya melakukan proses memengaruhi, memotivasi, dan mendukung usaha yang memungkinkan orang lain memberikan kontribusi pada pencapaian tujuan organisasi. Kepemimpinan lebih berhubungan dengan efisiensi 
(Munandar, 2001). Kepemimpinan merupakan proses mengarahkan dan memengaruhi aktivitas yang berkaitan dengan tugas dari para anggota kelompok yang memuat tiga implikasi penting, yaitu melibatkan orang lain, mencakup distribusi kekuasaan yang tidak sama di antara pemimpin dan anggota kelompok, serta kemampuan untuk menggunakan berbagai bentuk kekuasaan untuk memengaruhi perilaku pengikut melalui sejumlah cara. Gaya kepemimpinan yang efektif merupakan persyaratan vital bagi kelangsungan hidup dan keberhasilan organisasi.

Salah satu gaya kepemimpinan yang dianggap efektif dalam meningkatkan kinerja perusahaan adalah gaya kepemimpinan partisipatif. Gaya kepemimpinan partisipatif yaitu gaya yang secara aktif melibatkan bawahan dalam penetapan tujuan dengan menggunakan teknik-teknik manajemen partisipasif dan memusatkan perhatian baik terhadap karyawan dan tugas. Perilaku pemimpin menekankan pada banyak meningkatkan hubungan dan dukungan, sedikit memberikan pengarahan. Pemimpin ini cenderung bersedia tukar menukar pemikiran dan ide dengan bawahannya untuk menyusun keputusan bersama-sama serta mendukung usaha-usaha bawahannya dalam menyelesaikan tugas-tugasnya. Gaya kepemimpinan partisipatif merupakan gaya kepemimpinan dengan cara memimpin memberikan kesempatan kepada bawahan untuk ikut secara aktif baik mental, spiritual, fisik, maupun material dalam kiprah di organisasi (Soelistya, 2014). Dengan adanya kesempatan yang diberikan oleh pimpinan kepada bawahan dalam setiap aktivitas perusahaan, maka karyawan akan lebih merasa dihargai sehingga dapat terdorong untuk menunjukkan daya upaya guna meningkatkan kinerjanya.

Soelistya (2014) dalam penelitiannya menemukan bahwa terdapat pengaruh gaya kepemimpinan partisipatif terhadap prestasi kerja pegawai. Begitu juga dengan Soegihartono (2012) yang melakukan penelitian tentang pengaruh kepemimpinan dan kepuasan kerja terhadap kinerja dengan mediasi komitmen menunjukkan bahwa kepemimpinan mempunyai pengaruh yang positif terhadap kinerja. Untuk menciptakan kepemimpinan yang kondusif seorang pimpinan harus bisa memahami bawahannya dengan pandangan-pandangan yang disampaikan oleh bawahannya, pimpinan selalu memandang bahwa bawahan dalam melakukan pekerjaannya selalu ada kekurangannya. Pimpinan yang kurang mampu menyelesaikan masalah, dimana dalam pengambilan keputusan untuk memecahkan masalah tidak melibatkan bawahan mengenai bagaimana diambil solusi yang terbaik dengan cara-cara baru. Gaya kepemimpinan partisipastif yang mampu mengerti kondisi bawahan dan dapat memberikan solusi atas kesulitan dalam menyelesaikan pekerjaan akan menumbuhkan kepercayaan bawahan terhadap kemampuan pimpinan dan dapat berdampak positif terhadap kinerja karyawan KJPP Jimmy Prasetyo \& Rekan.

Kepemimpinan partisipatif akan semakin efektif dalam meningkatkan kinerja karyawan KJPP Jimmy Prasetyo \& Rekan apabila ditunjang dengan adanya komunikasi organisasi yang efektif pula. Sebagaimana pendapat yang diutarakan oleh Wexley dan Yuki (2005) bahwa komunikasi merupakan suatu proses yang vital dalam organisasi karena komunikasi diperlukan bagi efektivitas kepemimpinan, perencanaan, pengendalian, koordinasi, latihan, manajemen konflik, serta proses-proses organisasi lainnya.

Wibowo (2013) menyatakan bahwa komunikasi dalam organisasi mempunyai empat fungsi, yaitu control, motivation, emotional expression, dan information. Komunikasi organisasi yang berjalan efektif, baik pada jaringan komunikasi ke bawah (downward communication), komunikasi kepada atasan (upward communication), 
ataupun komunikasi horizontal (horizontal communication) akan semakin menjadikan setiap informasi tersampaikan dengan baik. Segala bentuk kendala yang dihadapi perusahaan dalam rangka mencapai kinerja yang maksimal akan dapat disampaikan guna dicari pemecahannya, sehingga perusahaan dapat mencapai kinerja yang maksimal. Boateng dan Jeduah (2014) dalam penelitiannya menyatakan bahwa komunikasi organisasi berpengaruh positif terhadap kinerja karyawan bank. Begitu juga dengan Triana, dkk (2016) dalam penelitiannya menyatakan bahwa komunikasi organisasi memiliki pengaruh signifikan terhadap kinerja karyawan Hotel Gajah Mada Graha Malang.

KJPP Jimmy Prasetyo \& Rekan dalam upaya meningkatkan kinerja karyawan juga harus memperhatikan faktor kepuasan kerja karyawan. Wibowo (2013: 132) menyatakan bahwa kepuasan kerja merupakan tingkat perasaan senang seseorang sebagai penilaian positif terhadap pekerjaannya dan lingkungan tempat pekerjaannya. Ketidakpuasan dalam kerja akan dapat menimbulkan perilaku agresif, atau sebaliknya akan menunjukkan sikap menarik diri dari kontrak dengan lingkungan sosialnya. Misalnya, dengan mengambil sikap berhenti dari perusahaan, suka bolos dan perilaku lain yang cenderung bersifat menghindar dari aktivitas organisasi. Bentuk perilaku agresif sebagai ungkapan ketidakpuasan dalam bekerja, misalnya melakukan sabotase, sengaja membuat kesalahan dalam kerja, menentang atasan atau sampai pada aktivitas pemogokan (Sutrisno, 2009).

Hasil penelitian tentang pengaruh kepuasan kerja terhadap kinerja yang dilakukan Suwardi dan Utomo (2011) menunjukkan bahwa kepuasan kerja berkorelasi positif dengan kinerja. Hal ini berarti bahwa karyawan yang tingkat kepuasan kerjanya tinggi akan memiliki sikap positif terhadap pekerjaannya, sehingga dapat menunjukkan kinerja yang maksimal guna memenuhi tanggung jawab yang diterima dalam pekerjaan. Robbins dan Judge (2008) menyatakan bahwa kepuasan kerja adalah suatu perasaan positif tentang pekerjaan seseorang yang merupakan hasil evaluasi karakteristiknya. Pekerja dengan tingkat ketidakpuasan yang tinggi lebih mungkin untuk melakukan sabotase atau kecurangan dan agresi yang pasif, atau sebaliknya akan menunjukkan sikap menarik diri dari kontrak dengan lingkungan sosialnya. Misalnya, dengan mengambil sikap berhenti dari perusahaan, suka bolos dan perilaku lain yang cenderung bersifat menghindar dari aktivitas organisasi. Ketidakpuasan yang dirasakan karyawan KJPP Jimmy Prasetyo \& Rekan dapat menimbulkan dampak yang besar, termasuk kegagalan pencapaian target perusahaan.

Pentingnya gaya kepemimpinan partisipatif, komunikasi organisasi dan kepuasan kerja telah terbukti dari beberapa penelitian terdahulu efektif dalam meningkatkan kinerja karyawan. Akan tetapi, terdapat pula research gap diantara penelitian-penelitian tersebut dan dapat dilihat pada tabel riset gap di bawah ini.

\section{Tabel 1 \\ Riset Gap}

\begin{tabular}{|c|l|l|c|}
\hline No. & \multicolumn{1}{|c|}{ Riset GAP } & \multicolumn{1}{|c|}{ Hasil } & Peneliti/Tahun \\
\hline 1. & $\begin{array}{l}\text { Terdapat hasil } \\
\text { penelitian yang } \\
\text { berbeda-beda } \\
\text { mengenai pengaruh } \\
\text { gaya kepemimpinan } \\
\text { partisipatif terhadap } \\
\text { kinerja }\end{array}$ & $\begin{array}{l}\text { Gaya } \\
\text { partisipatif berpengaruh positif } \\
\text { dan signifikan terhadap } \\
\text { prestasi kerja pegawai. }\end{array}$ & $\begin{array}{l}\text { Djoko Soelistya } \\
\text { (2014) }\end{array}$ \\
$\begin{array}{l}\text { partisipatif tidak berpengaruh } \\
\text { signifikan terhadap kinerja }\end{array}$ & $\begin{array}{c}\text { Andre Setiawan } \\
\text { (2017) }\end{array}$ \\
\hline
\end{tabular}




\begin{tabular}{|c|l|l|c|}
\hline 2. & karyawan. & \\
\hline $\begin{array}{l}\text { Terdapat hasil } \\
\text { penelitian yang } \\
\text { berbeda-beda } \\
\text { mengenai pengaruh } \\
\text { komunikasi } \\
\begin{array}{l}\text { organisasi terhadap } \\
\text { kinerja }\end{array}\end{array}$ & $\begin{array}{l}\text { Komunikasi organisasi } \\
\text { berpengaruh positif dan } \\
\text { signifikan terhadap kinerja } \\
\text { karyawan bank }\end{array}$ & $\begin{array}{c}\text { Owusu-Boateng, } \\
\text { W. and Jeduah. } \\
\text { B. A (2014) }\end{array}$ \\
\cline { 2 - 4 } & $\begin{array}{l}\text { Komunikasi organisasi tidak } \\
\text { berpengaruh terhadap kinerja } \\
\text { karyawan. }\end{array}$ & $\begin{array}{l}\text { S. O. Adeogun, } \\
\text { B. G. Abiona, T. } \\
\text { D. Ajayi and W. } \\
\text { Amuludun } \\
\text { (2016) }\end{array}$ \\
\hline
\end{tabular}

Sumber: Hasil Reduksi Data oleh Peneliti, 2018

Berangkat dari permasalahan faktual, yaitu masih belum tercapainya target kerja karyawan KJPP Jimmy Prasetyo \& Rekan yang dapat berdampak luas pada menurunnya kepercayaan pengguna jasa penilaian, dan adanya gap diantara penelitian-penelitian terdahulu, menjadikan topik kinerja karyawan KJPP Jimmy Prasetyo \& Rekan menarik untuk diteliti.

Berdasarkan kajian tentang riset gap dan fenomena yang terjadi, maka dapat dirumuskan masalah penelitian. Rumusan masalah penelitian adalah bagaimana mengoptimalkan kinerja karyawan dengan kepuasan kerja sebagai variabel intervening pada KJJP Jimmy Prasetyo \& Rekan, sehingga timbul pertanyaan dalam penelitian ini adalah sebagai berikut :

1. Bagaimana pengaruh gaya kepemimpinan partisipatif terhadap kepuasan kerja karyawan pada KJPP Jimmy Prasetyo \& Rekan?

2. Bagaimana pengaruh komunikasi organisasi terhadap kepuasan kerja karyawan pada KJPP Jimmy Prasetyo \& Rekan?

3. Bagaimana pengaruh kepuasan kerja terhadap kinerja karyawan pada KJPP Jimmy Prasetyo \& Rekan?

4. Bagaimana pengaruh gaya kepemimpinan partisipatif terhadap kinerja karyawan pada KJPP Jimmy Prasetyo \& Rekan?

5. Bagaimana pengaruh komunikasi organisasi terhadap kinerja karyawan pada KJPP Jimmy Prasetyo \& Rekan?

Penelitian ini bertujuan untuk mengetahui pengaruh gaya kepemimpinan partisipatif, komunikasi organisasi terhadap kinerja karyawan melalui kepuasan kerja sebagai variabel intervening.

\section{TELAAH PUSTAKA}

Hubungan Gaya Kepemimpinan Partisipatif dengan Kepuasan Kerja Karyawan pada KJPP Jimmy Prasetyo \& Rekan

Kepuasan kerja merupakan hal yang bersifat individual. Menurut Kreitner \& Kinicki (2005), bahwa kepuasan kerja sebagai efektivitas atau respon emosional terhadap berbagai aspek pekerjaan. Oleh sebab itu, kepuasan kerja sangat dipengaruhi oleh faktor lingkungan kerja masing-masing individu. Semakin banyak faktor yang mendukung individu di dalam melakukan pekerjaannya, maka akan semakin besar pula kepuasan di dalam bekerja. Kepemimpinan merupakan elemen penting di suatu perusahaan. 
Menurut Badeni (2013) pemimpin yang demokratis atau partisipatif mendesentralisasikan otoritas kepada karyawan. Hal ini berdampak pada keputusankeputusan yang dibuat tidak secara sepihak tetapi secara partisipatif. Seolah dipertegas, Gruenberg (1980) menyatakan bahwa adanya indikasi turunnya semangat dan kegairahan kerja ditunjukkan dengan tingginya tingkat absensi dan perpindahan pegawai dimana hal ini muncul sebagai akibat dari kepemimpinan yang tidak disenangi. Dari kedua pendekatan tersebut dapat ditarik kesimpulan bahwa gaya kepemimpinan memiliki dampak (pengaruh) yang nyata pada kepuasan kerja karyawan. Junaedi, dkk (2016) dalam penelitianya menemukan bahwa gaya kepemimpinan berpengaruh signifikan terhadap kepuasan kerja. Mengacu pada uraian tersebut maka dapat dirumuskan hipotesis sebagai berikut:

H1 : Terdapat pengaruh positif gaya kepemimpinan partisipatif terhadap kepuasan kerja karyawan pada KJPP Jimmy Prasetyo \& Rekan

\section{Hubungan Komunikasi Organisasi dengan Kepuasan Kerja Karyawan pada KJPP Jimmy Prasetyo \& Rekan}

Kepuasan kerja merupakan respons seseorang (sebagai pengaruh) terhadap bermacam-macam lingkungan kerja yang dihadapinya. Termasuk ke dalam hal ini respon terhadap komunikasi organisasi, supervisor, kompensasi, promosi, teman sekerja, kebijakan organisasi, dan hubungan interpersonal dalam organisasi. Hasil penelitian Navy O'Reilly dan Robert (dalam Muhammad, 2001) menunjukkan bahwa terdapat hubungan kualitas dan kuantitas komunikasi dengan kinerja organisasi.

Prabawa (2013) dalam penelitian berjudul Pengaruh Komunikasi Organisasi dan Gaya Kepemimpinan terhadap Kinerja Karyawan dengan Budaya Organisasi sebagai Variabel Intervening (Studi Kasus Pada PT.TWC Borobudur, Prambanan dan Ratu Boko). Hasil analisis menyatakan bahwa komunikasi yang terbuka antara manajemen dan karyawan adalah cara yang efektif dalam meningkatkan kinerja karyawan baik pada pekerjaan standar mereka dan peran ekstra dalam pekerjaan karena komunikasi merupakan sinyal bahwa bahwa organisasi peduli dengan kesejahteraan dan nilai kontribusi karyawan.

Mengacu pada uraian tersebut maka dapat dirumuskan hipotesis sebagai berikut:

H2 : Terdapat pengaruh positif komunikasi organisasi terhadap kepuasan kerja karyawan pada KJPP Jimmy Prasetyo \& Rekan

\section{Hubungan Kepuasan Kerja dengan Kinerja Karyawan pada KJPP Jimmy Prasetyo \& Rekan}

Kepuasan kerja merupakan suatu sikap yang positif yang menyangkut penyesuaian diri yang sehat dari para karyawan terhadap kondisi dan situasi kerja yang termasuk di dalamnya upah, kondisi sosial, kondisi fisik dan kondisi psikologis. Perasaan tertekan menjadikan seseorang tidak rasional, cemas, tegang, tidak dapat memusatkan perhatian pada pekerjaan dan gagal menikmati perasaan gembira atau puas terhadap pekerjaan yang dilakukannya. Dariyo (2004) menyatakan bahwa kepuasan kerja karyawan tergantung bagaimana penilaian (persepsi) individu yang bersangkutan terhadap pekerjaan itu sendiri, apakah membuat dirinya merasa puas atau tidak. Terpenuhinya kepuasan kerja dapat mendorong karyawan berusaha untuk menunjukkan upaya yang maksimal guna mencapai hasil kerja sesuai target yang ditetapkan. Ali, dkk (2013) dalam penelitiannya menemukan bahwa kepuasan kerja berpengaruh signifikan terhadap kinerja pegawai pada Badan Ketahanan Pangan dan Pelaksana Penyuluhan 
Daerah Kota Samarinda. Begitu juga halnya dengan Chandraningtyas (2012) yang menemukan bahwa kepuasan kerja berpengaruh terhadap kinerja karyawan PT. Kusuma Karya Persada yang outsourcing di PT. Sasa Inti Probolinggo. Mengacu pada uraian tersebut maka dapat dirumuskan hipotesis sebagai berikut:

H3 : Terdapat pengaruh positif kepuasan kerja terhadap kinerja karyawan pada KJPP Jimmy Prasetyo \& Rekan

\section{Hubungan Gaya Kepemimpinan Partisipatif dengan Kinerja Karyawan pada KJPP Jimmy Prasetyo \& Rekan}

Penerapan gaya kepemimpinan yang tepat maka bawahan akan respek dalam bekerja dan bersedia memberikan kontribusi yang terbaik. Ketepatan dalam memberikan tugas sesuai kapasitas dan kapabilitas bawahan akan mendorong pelaksana tugas berusaha memaksimalkan kinerja yang dibebankan kepada karyawan. Kepemimpinan yang partisipatif yaitu berkomunikasi dengan para bawahan dan memperhitungkan opini dan saran karyawan. Gaya kepemimpinan ini akan memposisikan bawahan sebagai rekan dalam memecahkan masalah, adanya kesempatan untuk menyumbang saran kepada atasan akan menciptakan musyawarah secara vertikal dengan pimpinan. Sunarsih dan Helmiatin (2016) dalam penelitiannya menyatakan bahwa gaya kepemimpinan berpengaruh positif terhadap kinerja karyawan. Mengacu pada uraian tersebut maka dapat dirumuskan hipotesis sebagai berikut:

H4 : Terdapat pengaruh positif gaya kepemimpinan partisipatif terhadap kinerja karyawan pada KJPP Jimmy Prasetyo \& Rekan

\section{Hubungan Komunikasi Organisasi dengan Kinerja Karyawan pada KJPP Jimmy Prasetyo \& Rekan}

Eksistensi perusahaan dalam menjalankan usahanya tergantung dari peran karyawan, sebagai sumber daya manusia yang diharapkan dapat memberikan kontribusi berarti bagi perusahaan tempatnya bekerja. Karyawan yang mampu memberikan kontribusi bagi kelangsungan perusahaan adalah karyawan yang memiliki kinerja yang maksimal. Komunikasi menjadi penting dalam suatu organisasi karena komunikasi merupakan unsur pengikat bagian yang saling bergantung dalam sistem itu dan komunikasi memungkinkan struktur organisasi berkembang dengan memberikan alatalat kepada individu-individu yang terpisah untuk mengkoordinir aktivitas mereka sehingga tujuan dan sasaran organisasi dapat tercapai. Penelitian terdahulu yang dilakukan oleh Triana, dkk (2016) menunjukkan bahwa komunikasi organisasi memiliki pengaruh signifikan terhadap kinerja karyawan. Indayani (2013) juga menemukan bahwa terdapat pengaruh komunikasi organisasi terhadap kinerja pegawai di kantor kecamatan Bululawang. Mengacu pada uraian tersebut maka dapat dirumuskan hipotesis sebagai berikut:

H5 : Terdapat pengaruh positif komunikasi organisasi terhadap kinerja karyawan pada KJPP Jimmy Prasetyo \& Rekan

\section{METODE}

Dalam penelitian ini peneliti menggunakan pendekatan penelitian kuantitatif. Data yang digunakan dalam penelitian ini adalah data primer, yaitu data diperoleh secara langsung dengan membagi kuesioner atau daftar pertanyaan kepada KJPP Jimmy Prasetyo \& Rekan. Peneliti menggunakan semua anggota populasi sebagai sampel yang berjumlah 50 orang. Teknik pengumpulan data dalam penelitian ini dengan kuesioner 
yang disusun dengan menurunkan beberapa aspek yang terkait dengan variabel penelitian. Teknik analisis data yang digunakan, meliputi uji validitas dan reliabilitas, analisis deskriptif, analisis regresi linier berganda, uji F, uji-t, sobel test, analisis jalur, dan koefisien determinasi.

\section{HASIL DAN PEMBAHASAN}

\section{Deskripsi tentang Gaya Kepemimpinan Partisipatif (X1)}

Berdasarkan analisis deskriptif diketahui bahwa nilai rata-rata untuk variabel gaya kepemimpinan partisipatif (X1) sebesar 29,02 dan termasuk dalam kategori sedang. Dari hasil tersebut menunjukkan bahwa gaya kepemimpinan partisipatif yang diterapkan di perusahaan cukup baik terdapat pada indikator atasan mampu memahami kesulitan bawahan dalam bekerja sebesar 30,4. Menunjukkan bahwa kemampuan atasan memahami kesulitan karyawan sudah cukup. Indeks terendah terdapat pada indikator atasan sepenuhnya percaya terhadap kemampuan bawahan dengan indeks sebesar 27 yang termasuk dalam kategori sedang. Hal tersebut menunjukkan bahwa kepercayaan atasan kepada karyawan dirasa belum cukup memenuhi harapan karyawan.

\section{Deskripsi tentang Komunikasi Organisasi (X2)}

Berdasarkan analisis deskriptif diketahui bahwa nilai rata-rata untuk variabel komunikasi organisasi (X2) sebesar 35,13 dan termasuk dalam kategori sedang. Dari hasil tersebut menunjukkan bahwa komunikasi organisasi yang diterapkan di perusahaan cukup baik terdapat pada indikator koordinasi yang terjalin antar rekan kerja berjalan efektif sebesar 39,8. Menunjukkan bahwa koordinasi yang terjalin antar rekan kerja sudah cukup baik. Indeks terendah terdapat pada indikator bawahan menanyakan kepada atasan mengenai ketidakjelasan pekerjaan dengan indeks sebesar 31,4 yang termasuk dalam kategori sedang. Hal tersebut menunjukkan bahwa bawahan telah menanyakan kepada atasan mengenai ketidakjelasan pekerjaan.

\section{Deskripsi tentang Kepuasan Kerja (Y1)}

Berdasarkan analisis deskriptif diketahui bahwa nilai rata-rata untuk variabel kepuasan kerja (Y1) sebesar 33,54 dan termasuk dalam kategori sedang. Dari hasil tersebut menunjukkan bahwa karyawan cukup merasakan kepuasan kerja terdapat pada indikator karyawan mendapatkan kesempatan untuk menggunakan bakat dalam bekerja sebesar 32,6. Indeks terendah terdapat pada indikator mendapatkan kesempatan untuk mengemukan ide-ide dengan indeks sebesar 30,8 yang termasuk dalam kategori sedang. Hal tersebut menunjukkan bahwa karyawan belum sepenuhnya mendapatkan kesempatan untuk mengemukan ide-ide yang dimiliki dalam bekerja.

\section{Deskripsi tentang Kinerja Karyawan (Y2)}

Berdasarkan analisis deskriptif diketahui bahwa nilai rata-rata untuk variabel gaya kinerja karyawan (Y2) sebesar 32,38 dan termasuk dalam kategori sedang. Dari hasil tersebut menunjukkan bahwa kinerja yang ditunjukkan karyawan cukup baik terdapat pada indikator kesediaan membantu pekerjaan rekan kerja yang belum selesai sebesar 36,6. Indeks terendah terdapat pada indikator kesediaan meluangkan waktu sharing mengenai pekerjaan dengan rekan kerja dengan indeks sebesar 29,8 yang termasuk dalam kategori sedang. Hal tersebut menunjukkan bahwa karyawan masih belum sepenuhnya menunjukkan kesediaan untuk saling bertukar pikiran mengenai pekerjaan. 


\section{Analisis Regresi Linier Berganda Variabel Gaya Kepemimpinan Partisipatif dan Komunikasi Organisasi terhadap Kepuasan Kerja}

Dalam menganalisa pengaruh gaya kepemimpinan partisipatif dan komunikasi organisasi terhadap kepuasan kerja dilakukan dengan menggunakan analisis regresi berdasarkan nilai standardized coefficients dari masing-masing variabel yang diteliti.

\section{Tabel 2}

Hasil Analisis Regresi Berganda Gaya Kepemimpinan Partisipatif dan Komunikasi Organisasi terhadap Kepuasan Kerja

\begin{tabular}{|l|r|r|r|r|r|}
\hline \multirow{2}{*}{ Model } & \multicolumn{2}{|c|}{$\begin{array}{c}\text { Unstandardized } \\
\text { Coefficients }\end{array}$} & $\begin{array}{c}\text { Standardized } \\
\text { Coefficients }\end{array}$ & \multirow{2}{*}{ Sig. } \\
\cline { 2 - 5 } & \multicolumn{1}{|c|}{ B } & Std. Error & Beta & & \\
\hline \multirow{2}{*}{ (Constant) } & 10,746 & 4,426 & & 2,428 &, 019 \\
$\quad$ Gaya Kepemimpinan &, 306 &, 125 &, 342 & 2,453 &, 018 \\
$\quad$ Partisipatif &, 240 &, 098 &, 340 & 2,443 &, 018 \\
\hline
\end{tabular}

a. Dependent Variable: Kepuasan Kerja

Sumber : Data Primer yang Telah Diolah, 2018

Berdasarkan tabel 2 tersebut terlihat variabel gaya kepemimpinan partisipatif, dan komunikasi organisasi berpengaruh positif terhadap kepuasan kerja dengan signifikan < 0.05. Dari tabel tersebut juga dapat dibuat persamaan matematis sebagai berikut:

$$
\hat{\mathrm{Y}} 1=0,342 \mathrm{X} 1+0,340 \mathrm{X} 2
$$

$$
\begin{aligned}
& \text { Keterangan: } \\
& \text { Y1 = Kepuasan kerja } \\
& \text { X1 = Gaya kepemimpinan partisipatif } \\
& \text { X2 = Komunikasi organisasi }
\end{aligned}
$$

a. Nilai koefisien regresi variabel gaya kepemimpinan partisipatif (X1) sebesar 0,342 bernilai positif dengan taraf signifikansi 0,018 (lebih kecil dari 0,05 ) artinya gaya kepemimpinan partisipatif berpengaruh positif dan signifikan terhadap kepuasan kerja.

b. Nilai koefisien regresi variabel komunikasi organisasi (X2) sebesar 0,340 bernilai positif dengan taraf signifikansi 0,018 (lebih kecil dari 0,05) artinya komunikasi organisasi berpengaruh positif dan signifikan terhadap kepuasan kerja.

Secara umum dari model persamaan ini dapat dikatakan bahwa gaya kepemimpinan partisipatif dan komunikasi organisasi secara umum bernilai positif terhadap kepuasan kerja. Namun demikian, dari hasil perhitungan dapat diketahui bahwa masing-masing variabel bebas, yaitu gaya kepemimpinan partisipatif dan komunikasi organisasi memberikan pengaruh yang berbeda satu sama lain. Gaya kepemimpinan partisipatif lebih berpengaruh kuat dalam peningkatan kepuasan kerja.

Analisis Regresi Linier Berganda Variabel Gaya Kepemimpinan Partisipatif dan Komunikasi Organisasi terhadap Kinerja Karyawan melalui Kepuasan Kerja

Dalam menganalisa pengaruh gaya kepemimpinan partisipatif dan komunikasi organisasi terhadap kinerja karyawan melalui kepuasan kerja dilakukan dengan menggunakan analisis regresi berdasarkan nilai standardized coefficients dari masingmasing variabel yang diteliti. 
Tabel 3

Hasil Analisis Regresi Berganda Gaya Kepemimpinan Partisipatif, Komunikasi Organisasi, dan Kepuasan Kerja terhadap Kinerja Karyawan

\begin{tabular}{|c|c|c|c|c|c|}
\hline \multirow[t]{2}{*}{ Model } & \multicolumn{2}{|c|}{$\begin{array}{c}\text { Unstandardized } \\
\text { Coefficients }\end{array}$} & $\begin{array}{l}\text { Standardized } \\
\text { Coefficients }\end{array}$ & \multirow[t]{2}{*}{$\mathrm{t}$} & \multirow[t]{2}{*}{ Sig. } \\
\hline & B & Std. Error & Beta & & \\
\hline \multirow{4}{*}{$\begin{array}{l}\text { (Constant) } \\
\text { Gaya Kepemimpinan } \\
\text { Partisipatif } \\
\text { Komunikasi Organisasi } \\
\text { Kepuasan Kerja }\end{array}$} & 6,047 & 4,221 & & 1,433 & , 159 \\
\hline & ,302 & ,119 & ,309 & 2,537 & ,015 \\
\hline & 197 & ,094 & ,255 & 2,100 & ,041 \\
\hline & ,382 & ,131 & ,349 & 2,913 & ,006 \\
\hline
\end{tabular}

a. Dependent Variable: Kinerja Karyawan

Sumber : Data Primer yang Telah Diolah, 2018

Berdasarkan tabel 3 tersebut dapat dibuat persamaan matematis sebagai berikut:

$$
\hat{\mathrm{Y}} 2=0,309 \mathrm{X} 1+0,255 \mathrm{X} 2+0,349+\mathrm{Y} 1
$$

Keterangan:

Y2 = Kinerja karyawan

Y1 = Kepuasan kerja

$\mathrm{X} 1=$ Gaya kepemimpinan partisipatif

$\mathrm{X} 2=$ Komunikasi organisasi

a. Nilai koefisien regresi variabel gaya kepemimpinan partisipatif (X1) sebesar 0,309 bernilai positif dengan taraf signifikansi 0,015 (lebih kecil dari 0,05 ) artinya gaya kepemimpinan partisipatif berpengaruh positif dan signifikan terhadap kinerja karyawan.

b. Nilai koefisien regresi variabel komunikasi organisasi (X2) sebesar 0,255 bernilai positif dengan taraf signifikansi 0,041 (lebih kecil dari 0,05) artinya komunikasi organisasi berpengaruh positif dan signifikan terhadap kinerja karyawan.

c. Nilai koefisien regresi variabel kepuasaan kerja (Y1) sebesar 0,349 bernilai positif dengan taraf signifikansi 0,006 (lebih kecil dari 0,05) artinya kepuasaan kerja berpengaruh positif dan signifikan terhadap kinerja karyawan.

\section{Uji Model (Uji-F)}

Uji F pada dasarnya menunjukkan apakah semua variabel bebas yang dimasukkan dalam model mempunyai pengaruh secara bersama-sama terhadap variabel dependen (Ghozali, 2011). Pengujian ANOVA dapat dilihat pada tabel berikut:

\section{Tabel 4}

\begin{tabular}{|c|c|c|}
\hline \multicolumn{3}{|c|}{ Uji-F } \\
\hline & $\mathbf{F}$ & Sig. \\
\hline \multicolumn{3}{|l|}{ Persamaan Regresi I } \\
\hline Komunikasi organisasi & \multirow{2}{*}{18,483} & \multirow{2}{*}{0,000} \\
\hline Gaya kepemimpinan partisipatif & & \\
\hline \multicolumn{3}{|l|}{ Persamaan Regresi II } \\
\hline Komunikasi organisasi & \multirow{3}{*}{27,090} & \multirow{3}{*}{0,000} \\
\hline Gaya kepemimpinan partisipatif & & \\
\hline Kepuasan kerja & & \\
\hline
\end{tabular}

Sumber : Data Primer yang Telah Diolah, 2018 
Pada tabel 4 dapat diketahui bahwa nilai probabilitas signifikan 0,000 kurang dari $5 \%$, sehingga dapat disimpulkan bahwa gaya kepemimpinan partisipatif, komunikasi organisasi, dan kepuasan kerja berpengaruh terhadap kinerja karyawan pada KJPP Jimmy Prasetyo \& Rekan.

\section{Koefisien Determinasi}

Analisis determinan dalam regresi linier berganda digunakan untuk mengetahui persentase sumbangan pengaruh variabel independen secara serentak terhadap variabel dependen. Untuk mengetahui persentase pengaruh variabel independen terhadap variabel dependen digunakan koefisien determinan.

Tabel 5

Koefisien Determinasi

\begin{tabular}{|c|c|}
\hline Persamaan Regresi I & \multirow{2}{*}{$\begin{array}{c}\text { Adjusted R } \\
\text { Square }\end{array}$} \\
\hline Komunikasi organisasi & \multirow{2}{*}{0,332} \\
\hline Gaya kepemimpinan partisipatif & \\
\cline { 1 - 1 } Persamaan Regresi II & \\
\cline { 1 - 1 } Komunikasi organisasi & \multirow{2}{*}{0,548} \\
\cline { 1 - 1 } Gaya kepemimpinan partisipatif & \\
\hline Kepuasan kerja & \\
\hline
\end{tabular}

Dari tabel 5 di atas menunjukkan dapat dihitung total $\mathrm{R}^{2}$ dengan langkah-langkah sebagai berikut:

1) Menghitung Error term (unsur gangguan/kesalahan penganggu)

$$
\begin{aligned}
\mathrm{e}_{1} & =\sqrt{1-\left(R_{1}\right)^{2}} \\
& =\sqrt{1-(0.332})^{2} \\
& =\sqrt{0.889776} \\
& =0.943 \\
\mathrm{e}_{2} & =\sqrt{1-\left(R_{2}\right)^{2}} \\
& =\sqrt{1-(0.548)^{2}} \\
& =\sqrt{0.889776} \\
& =0.836
\end{aligned}
$$

2) Total $R^{2}$

$$
\begin{aligned}
& =1-\left(\mathrm{e}_{1}\right)^{2} \cdot\left(\mathrm{e}_{2}\right)^{2} \\
& =1-(0.943)^{2} \cdot(0.836)^{2} \\
& =1-0,621 \\
& =0,379
\end{aligned}
$$

Dari tabel 5 di atas menunjukkan bahwa total $\mathrm{R}^{2}$ adalah 0,379. Hal ini menunjukkan bahwa 37,9\% variabel kinerja karyawan dapat dijelaskan oleh gaya kepemimpinan partisipatif, komunikasi organisasi, dan kepuasan kerja, sedangkan sisanya sebesar $62,1 \%$ dijelaskan oleh variabel lain di luar model penelitian.

\section{Uji Hipotesis (Uji-t)}

Uji parsial atau uji t dilakukan untuk mengetahui pengaruh variabel independen (X) terhadap variabel dependen (Y). Jika probabilitas (dalam tabel ditandai dengan Sig (p) $<0,05$, maka $\mathrm{H}_{0}$ ditolak dan sebaliknya jika probabilitas $>0,05$, maka $\mathrm{H}_{0}$ diterima 
artinya tidak ada pengaruh secara signifikan. Hasil analisis uji parsial (Uji t) dalam penelitian ini dapat dijelaskan sebagai berikut:

\section{Tabel 6}

\section{Uji-t}

\begin{tabular}{|c|c|c|c|c|c|}
\hline \multirow[t]{2}{*}{ Model } & \multicolumn{2}{|c|}{$\begin{array}{c}\text { Unstandardized } \\
\text { Coefficients } \\
\end{array}$} & \multirow{2}{*}{$\begin{array}{c}\begin{array}{c}\text { Standardized } \\
\text { Coefficients }\end{array} \\
\text { Beta }\end{array}$} & \multirow[t]{2}{*}{$\mathrm{t}$} & \multirow[t]{2}{*}{ Sig. } \\
\hline & B & Std. Error & & & \\
\hline (Constant) & 10,746 & 4,426 & & 2,428 & ,019 \\
\hline $\begin{array}{l}1 \text { Gaya Kepemimpinan } \\
\text { Partisipatif }\end{array}$ & ,306 & 125 & ,342 & 2,453 & ,018 \\
\hline Komunikasi Organisasi & 240 & ,098 & ,340 & 2,443 & ,018 \\
\hline
\end{tabular}

a. Dependent Variable: Kepuasan Kerja

Sumber : Data Primer yang Telah Diolah, 2018

Dilihat dari tabel 6 maka pengujian hipotesis dapat dijelaskan sebagai berikut :

1. Pengujian Hipotesis 1 (H1)

Berdasarkan hasil pengujian hipotesis (uji t) variabel gaya kepemimpinan partisipatif diperoleh nilai t-hitung sebesar 2,453 dengan nilai signifikansi sebesar $0,018(<0,05)$. Tabel distibusi t dicari pada $\mathrm{a}=5 \%: 2=2,5 \%$ (uji 2 sisi) dengan derajat kebebasan $(\mathrm{df})=\mathrm{n}-\mathrm{k}-1=50-2-1=47, \mathrm{n}$ adalah jumlah kasus (sampel), $\mathrm{k}$ adalah jumlah variabel independen), sehingga diperoleh $\mathrm{t}$ tabel sebesar 2,011 (dicari di MsExcel dengan cara $=\operatorname{tinv}(0.05,47)$.

Nilai t-hitung lebih besar dibandingkan nilai t-tabel $(2,453>2,011)$ dan nilai signifikan lebih kecil dari 0,05, sehingga dapat disimpulkan bahwa variabel gaya kepemimpinan partisipatif berpengaruh terhadap kepuasan kerja karyawan pada KJPP Jimmy Prasetyo \& Rekan atau H1 diterima.

2. Pengujian Hipotesis $2(\mathrm{H} 2)$

Berdasarkan hasil pengujian hipotesis (uji t) variabel komunikasi organisasi diperoleh nilai t-hitung sebesar 2,443 dengan nilai signifikansi sebesar 0,018 (< 0,05 ). Tabel distibusi t dicari pada $\mathrm{a}=5 \%: 2=2,5 \%$ (uji 2 sisi) dengan derajat kebebasan $(\mathrm{df})=\mathrm{n}-\mathrm{k}-1=50-2-1=47, \mathrm{n}$ adalah jumlah kasus (sampel), $\mathrm{k}$ adalah jumlah variabel independen), sehingga diperoleh $\mathrm{t}$ tabel sebesar 2,011 (dicari di MsExcel dengan cara $=\operatorname{tinv}(0.05,47)$.

Nilai t-hitung lebih besar dibandingkan nilai t-tabel $(2,443>2,011)$ dan nilai signifikan lebih kecil dari 0,05 , sehingga dapat disimpulkan bahwa variabel komunikasi organisasi berpengaruh terhadap kepuasan kerja karyawan pada KJPP Jimmy Prasetyo \& Rekan atau $\mathbf{H 2}$ diterima.

Uji parsial atau uji $\mathrm{t}$ juga dilakukan untuk mengetahui pengaruh gaya kepemimpinan partisipatif, komunikasi organisasi, dan kepuasan kerja terhadap kinerja karyawan pada KJPP Jimmy Prasetyo \& Rekan. Hasil analisis uji parsial (Uji t) dalam penelitian ini dapat dijelaskan sebagai berikut: 


\section{Tabel 7}

Uji-t

\begin{tabular}{|c|c|c|c|c|c|}
\hline \multirow[t]{2}{*}{ Model } & \multicolumn{2}{|c|}{$\begin{array}{c}\text { Unstandardized } \\
\text { Coefficients }\end{array}$} & $\begin{array}{c}\text { Standardized } \\
\text { Coefficients }\end{array}$ & \multirow[t]{2}{*}{$\mathrm{t}$} & \multirow[t]{2}{*}{ Sig. } \\
\hline & $\mathrm{B}$ & Std. Error & Beta & & \\
\hline \multirow{4}{*}{$\begin{array}{l}\text { Partisipatif } \\
\text { Komunikasi Org } \\
\text { Kepuasan Kerja }\end{array}$} & 6,047 & 4,221 & & 1,433 &, 159 \\
\hline & ,302 & ,119 & ,309 & 2,537 & 015, \\
\hline & , 197 & ,094 & ,255 & 2,100 &, 041 \\
\hline & ,382 & ,131 & ,349, & 2,913 & ,006, \\
\hline
\end{tabular}

a. Dependent Variable: Kinerja Karyawan

Sumber : Data Primer yang Telah Diolah, 2018

Dilihat dari tabel 7 maka pengujian hipotesis dapat dijelaskan sebagai berikut :

3. Pengujian Hipotesis 3 (H3)

Berdasarkan hasil pengujian hipotesis (uji t) variabel kepuasan kerja diperoleh nilai t-hitung sebesar 2,913 dengan nilai signifikansi sebesar 0,001 $(<0,05)$. Tabel distibusi t dicari pada a $=5 \%: 2=2,5 \%$ (uji 2 sisi) dengan derajat kebebasan $(\mathrm{df})=$ $\mathrm{n}-\mathrm{k}-1=50-2-1=47, \mathrm{n}$ adalah jumlah kasus (sampel), $\mathrm{k}$ adalah jumlah variabel independen), sehingga diperoleh $\mathrm{t}$ tabel sebesar 2,011 (dicari di MsExcel dengan cara $=\operatorname{tinv}(0.05,47)$.

Nilai t-hitung lebih besar dibandingkan nilai t-tabel $(2,913>2,011)$ dan nilai signifikan lebih kecil dari 0,05, sehingga dapat disimpulkan bahwa variabel kepuasan kerja berpengaruh terhadap kinerja karyawan pada KJPP Jimmy Prasetyo \& Rekan atau $\mathbf{H 3}$ diterima.

4. Pengujian Hipotesis 4 (H4)

Berdasarkan hasil pengujian hipotesis (uji t) variabel gaya kepemimpinan partisipatif diperoleh nilai t-hitung sebesar 2,537 dengan nilai signifikansi sebesar $0,001(<0,05)$. Tabel distibusi t dicari pada $\mathrm{a}=5 \%: 2=2,5 \%$ (uji 2 sisi) dengan derajat kebebasan $(\mathrm{df})=\mathrm{n}-\mathrm{k}-1=50-2-1=47, \mathrm{n}$ adalah jumlah kasus (sampel), $\mathrm{k}$ adalah jumlah variabel independen), sehingga diperoleh $t$ tabel sebesar 2,011 (dicari di MsExcel dengan cara $=\operatorname{tinv}(0.05,47)$.

Nilai t-hitung lebih besar dibandingkan nilai t-tabel $(2,537>2,011)$ dan nilai signifikan lebih kecil dari 0,05, sehingga dapat disimpulkan bahwa variabel gaya kepemimpinan partisipatif berpengaruh terhadap kinerja karyawan pada KJPP Jimmy Prasetyo \& Rekan atau $\mathbf{H 4}$ diterima.

5. Pengujian Hipotesis 5 (H5)

Berdasarkan hasil pengujian hipotesis (uji t) variabel komunikasi organisasi diperoleh nilai t-hitung sebesar 2,100 dengan nilai signifikansi sebesar 0,001 (< 0,05 ). Tabel distibusi t dicari pada $\mathrm{a}=5 \%: 2=2,5 \%$ (uji 2 sisi) dengan derajat kebebasan $(\mathrm{df})=\mathrm{n}-\mathrm{k}-1=50-2-1=47, \mathrm{n}$ adalah jumlah kasus (sampel), $\mathrm{k}$ adalah jumlah variabel independen), sehingga diperoleh $\mathrm{t}$ tabel sebesar 2,011 (dicari di MsExcel dengan cara $=\operatorname{tinv}(0.05,47)$.

Nilai t-hitung lebih besar dibandingkan nilai t-tabel $(2,100>2,011)$ dan nilai signifikan lebih kecil dari 0,05 , sehingga dapat disimpulkan bahwa variabel komunikasi organisasi berpengaruh terhadap kinerja karyawan pada KJPP Jimmy Prasetyo \& Rekan atau $\mathbf{H 5}$ diterima. 


\section{Analisis Jalur (Path Analysis)}

Berikut ini analisis jalur menguji hubungan antara gaya kepemimpinan partisipatif terhadap kinerja karyawan pada KJPP Jimmy Prasetyo \& Rekan dan apakah hubungan gaya kepemimpinan partisipatif ke kinerja karyawan pada KJPP Jimmy Prasetyo \& Rekan dimediasi oleh variabel kepuasan kerja dan komunikasi organisasi terhadap kinerja karyawan pada KJPP Jimmy Prasetyo \& Rekan dengan persamaan dan apakah hubungan komunikasi organisasi ke kinerja karyawan pada KJPP Jimmy Prasetyo \& Rekan dimediasi oleh variabel kepuasan kerja seperti gambar berikut:

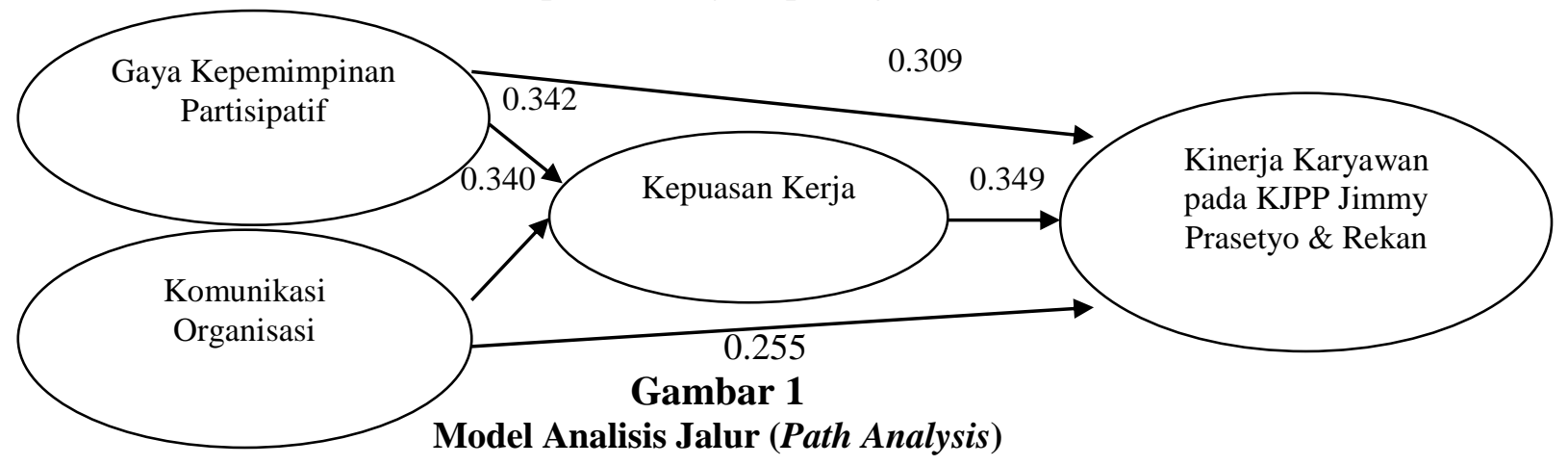

Berdasarkan gambar di atas diketahui bahwa pengaruh gaya kepemimpinan partisipatif dan komunikasi organisasi terhadap kepuasan kerja menunjukkan pengaruh yang signifikan. Kondisi ini dapat disimpulkan bahwa gaya kepemimpinan partisipatif dan komunikasi organisasi dapat berpengaruh langsung terhadap kinerja karyawan pada KJPP Jimmy Prasetyo \& Rekan maupun berpengaruh tidak langsung dengan dimediasi kepuasan kerja sebagai variabel intervening kemudian mempengaruhi kinerja karyawan pada KJPP Jimmy Prasetyo \& Rekan.

\section{Pembahasan}

\section{Hipotesis 1: Gaya Kepemimpinan Partisipatif Berpengaruh Positif terhadap Kepuasan Kerja Karyawan pada KJPP Jimmy Prasetyo \& Rekan}

Hasil penelitian ini menunjukkan bahwa variabel gaya kepemimpinan partisipatif diperoleh nilai koefisien regresi sebesar 2,453 dan signifikan pada 0,018. Hal ini berarti hipotesis yang menyatakan bahwa terdapat pengaruh positif gaya kepemimpinan partisipatif terhadap kepuasan kerja karyawan pada KJPP Jimmy Prasetyo \& Rekan diterima. Artinya, bila semakin baik gaya kepemimpinan partisipatif, maka akan semakin meningkat kepuasan kerja karyawan pada KJPP Jimmy Prasetyo \& Rekan. Maka, pimpinan KJPP Jimmy Prasetyo \& Rekan bila ingin meningkatkan kepemimpinan partisipatif, perlu meningkatkan pendelegasian wewenang kepada bawahan, keputusan yang diambil pemimpin melibatkan opini dari bawahan, komunikasi pemimpin dan bawahan dua arah, berorientasi pada hubungan, asumsi pada karyawan dapat bekerja sama dan bermoral, serta perencanaan tujuan dilakukan oleh keterlibatan karyawan. Menurut Badeni (2013) pemimpin yang demokratis atau partisipatif mendesentralisasikan otoritas kepada karyawan. Hal ini berdampak pada keputusan-keputusan yang dibuat tidak secara sepihak tetapi secara partisipatif. Pemimpin partisipatif mampu membangun semangat karyawan ataupun mendengarkan setiap ide dan gagasan dari karyawan, sehingga karyawan pada KJPP Jimmy Prasetyo \& Rekan dapat semakin terpuaskan.

Hasil penelitian ini sejalan dengan penelitian terdahulu yang dilakukan oleh Junaedi, dkk (2016) dalam penelitianya menemukan bahwa gaya kepemimpinan 
berpengaruh signifikan terhadap kepuasan kerja. Dengan adanya kesempatan yang diberikan oleh pimpinan kepada bawahan dalam setiap aktivitas perusahaan, maka karyawan akan lebih merasa dihargai sehingga dapat merasakan kepuasan kerja.

Gaya kepemimpinan partisipatif yaitu gaya yang secara aktif melibatkan bawahan dalam penetapan tujuan dengan menggunakan teknik- teknik manajemen partisipasif dan memusatkan perhatian baik terhadap karyawan dan tugas. Perilaku pemimpin menekankan pada banyak meningkatkan hubungan dan dukungan, sedikit memberikan pengarahan. Pemimpin ini cenderung bersedia tukar menukar pemikiran dan ide dengan bawahannya untuk menyusun keputusan bersama-sama serta mendukung usaha-usaha bawahannya dalam menyelesaikan tugas-tugasnya. Gaya kepemimpinan partisipatif merupakan gaya kepemimpinan dengan cara memimpin memberikan kesempatan kepada bawahan untuk ikut secara aktif baik mental, spiritual, fisik, maupun material dalam kiprah di organisasi (Soelistya, 2014). Gya kepemimpinan partisipatif memiliki dampak (pengaruh) yang nyata pada kepuasan kerja karyawan. Karyawan akan semakin merasakan kepuasan karena karyawan merasakan adanya penghargaan dari atasan ataupun kepercayaan yang diberikan oleh atasan kepada karyawan.

\section{Hipotesis 2: Komunikasi Organisasi Berpengaruh Positif terhadap Kepuasan Kerja Karyawan pada KJPP Jimmy Prasetyo \& Rekan}

Hasil penelitian ini menunjukkan bahwa variabel komunikasi organisasi diperoleh nilai koefisien regresi sebesar 2,443 dan signifikan pada 0,018. Hal ini berarti hipotesis yang menyatakan bahwa terdapat pengaruh positif komunikasi organisasi terhadap kepuasan kerja karyawan pada KJPP Jimmy Prasetyo \& Rekan diterima. Artinya, bila semakin baik komunikasi organisasi, maka akan semakin meningkat kepuasan kerja karyawan pada KJPP Jimmy Prasetyo \& Rekan. Makanya, bila ingin meningkatkan komunikasi organisasi, maka perlu ditingkatkan komunikasi ke bawah (downward communication), komunikasi ke atas (upward communication), serta komunikasi lateral.

Wibowo (2013) menyatakan bahwa komunikasi dalam organisasi mempunyai empat fungsi, yaitu control, motivation, emotional expression, dan information. Komunikasi organisasi yang berjalan efektif, baik pada jaringan komunikasi ke bawah (downward communication), komunikasi kepada atasan (upward communication), ataupun komunikasi horizontal (horizontal communication) akan semakin menjadikan setiap informasi tersampaikan dengan baik. Komunikasi yang terbuka antara manajemen dan karyawan adalah cara yang efektif dalam meningkatkan kinerja karyawan baik pada pekerjaan standar mereka dan peran ekstra dalam pekerjaan karena komunikasi merupakan sinyal bahwa bahwa organisasi peduli dengan kesejahteraan dan nilai kontribusi karyawan. Komunikasi organisasi yang berjalan efektif dapat semakin meningkatkan kepuasan kerja karyawan pada KJPP Jimmy Prasetyo \& Rekan.

\section{Hipotesis 3: Kepuasan Kerja Berpengaruh Positif terhadap Kinerja Karyawan pada KJPP Jimmy Prasetyo \& Rekan}

Hasil penelitian ini menunjukkan bahwa variabel kepuasan kerja diperoleh nilai koefisien regresi sebesar 2,913 dan signifikan pada 0,001. Hal ini berarti hipotesis yang menyatakan bahwa terdapat pengaruh positif kepuasan kerja terhadap kinerja karyawan pada KJPP Jimmy Prasetyo \& Rekan diterima. Artinya, bila semakin baik kepuasan kerja, maka akan semakin meningkat kinerja karyawan pada KJPP Jimmy Prasetyo \& Rekan. Makanya, bila ingin meningkatkan kepuasan kerja, maka perlu ditingkatkan ragam keterampilan (skill variety), identitas pekerjaan (task identity), kepentingan 
pekerjaan (task significance), otonomi (autonomy), serta umpan balik pekerjaan itu sendiri (feedback from the job it self).

Wibowo (2013) menyatakan bahwa kepuasan kerja merupakan tingkat perasaan senang seseorang sebagai penilaian positif terhadap pekerjaannya dan lingkungan tempat pekerjaannya. Hasil penelitian ini sejalan dengan penelitian yang dilakukan oleh Suwardi dan Utomo (2011) bahwa bahwa kepuasan kerja berkorelasi positif dengan kinerja. Hal ini berarti bahwa karyawan yang tingkat kepuasan kerjanya tinggi akan memiliki sikap positif terhadap pekerjaannya, sehingga dapat menunjukkan kinerja yang maksimal guna memenuhi tanggung jawab yang diterima dalam pekerjaan.

Ali, dkk (2013) dalam penelitiannya menemukan bahwa kepuasan kerja berpengaruh signifikan terhadap kinerja pegawai pada Badan Ketahanan Pangan dan Pelaksana Penyuluhan Daerah Kota Samarinda. Begitu juga halnya dengan Chandraningtyas (2012) yang menemukan bahwa kepuasan kerja berpengaruh terhadap kinerja karyawan PT. Kusuma Karya Persada yang outsourcing di PT. Sasa Inti Probolinggo. Terpenuhinya kepuasan kerja dalam diri karyawan pada KJPP Jimmy Prasetyo \& Rekan memiliki dampak yang besar bagi pencapaian target kerja. Karyawan yang terpuaskan akan dengan senang hati menunjukkan kemampuan yang dimiliki dalam bekerja, serta bersungguh-sungguh dalam melaksanakan setiap pekerjaan. Karyawan akan terdorong untuk mencapai target kerja yang ditetapkan oleh perusahaan, sehingga dapat berdampak pada tercapainya kinerja maksimal perusahaan.

\section{Hipotesis 4: Gaya Kepemimpinan Partisipatif Berpengaruh Positif terhadap Kinerja Karyawan pada KJPP Jimmy Prasetyo \& Rekan}

Hasil penelitian ini menunjukkan bahwa variabel gaya kepemimpinan partisipatif diperoleh nilai koefisien regresi sebesar 2,537 dan signifikan pada 0,001. Hal ini berarti hipotesis yang menyatakan bahwa terdapat pengaruh positif gaya kepemimpinan partisipatif terhadap kinerja karyawan pada KJPP Jimmy Prasetyo \& Rekan diterima. Artinya, bila semakin baik gaya kepemimpinan partisipatif, maka akan semakin meningkat kinerja karyawan pada KJPP Jimmy Prasetyo \& Rekan. Penerapan gaya kepemimpinan yang tepat maka bawahan akan respek dalam bekerja dan bersedia memberikan kontribusi yang terbaik. Ketepatan dalam memberikan tugas sesuai kapasitas dan kapabilitas bawahan akan mendorong pelaksana tugas berusaha memaksimalkan kinerja yang dibebankan kepada karyawan. Kepemimpinan yang partisipatif yaitu berkomunikasi dengan para bawahan dan memperhitungkan opini dan saran karyawan. Gaya kepemimpinan ini akan memposisikan bawahan sebagai rekan dalam memecahkan masalah, adanya kesempatan untuk menyumbang saran kepada atasan akan menciptakan musyawarah secara vertikal dengan pimpinan.

Hasil penelitian ini sejalan dengan penelitian yang dilakukan oleh Sunarsih dan Helmiatin (2016) bahwa gaya kepemimpinan berpengaruh positif terhadap kinerja karyawan. Gaya kepemimpinan partisipastif yang mampu mengerti kondisi bawahan dan dapat memberikan solusi atas kesulitan dalam menyelesaikan pekerjaan akan menumbuhkan kepercayaan bawahan terhadap kemampuan pimpinan dan dapat berdampak positif terhadap kinerja karyawan KJPP Jimmy Prasetyo \& Rekan.

\section{Hipotesis 5: Komunikasi Organisasi Berpengaruh Positif terhadap Kinerja Karyawan pada KJPP Jimmy Prasetyo \& Rekan}

Hasil penelitian ini menunjukkan bahwa variabel komunikasi organisasi diperoleh nilai koefisien regresi sebesar 2,100 dan signifikan pada 0,001. Hal ini berarti hipotesis 
yang menyatakan bahwa terdapat pengaruh positif komunikasi organisasi terhadap kinerja karyawan pada KJPP Jimmy Prasetyo \& Rekan diterima. Artinya, bila semakin baik gaya komunikasi organisasi, maka akan semakin meningkat kinerja karyawan pada KJPP Jimmy Prasetyo \& Rekan. Karyawan yang mampu memberikan kontribusi bagi kelangsungan perusahaan adalah karyawan yang memiliki kinerja yang maksimal. Komunikasi menjadi penting dalam suatu organisasi karena komunikasi merupakan unsur pengikat bagian yang saling bergantung dalam sistem itu dan komunikasi memungkinkan struktur organisasi berkembang dengan memberikan alat-alat kepada individu-individu yang terpisah untuk mengkoordinir aktivitas mereka sehingga tujuan dan sasaran organisasi dapat tercapai. Hasil penelitian ini sejalan dengan penelitian terdahulu yang dilakukan oleh Triana, dkk (2016) menunjukkan bahwa komunikasi organisasi memiliki pengaruh signifikan terhadap kinerja karyawan. Hasil penelitian ini juga sejalan dengan Indayani (2013) yang juga menemukan bahwa terdapat pengaruh komunikasi organisasi terhadap kinerja pegawai di kantor kecamatan Bululawang. Komunikasi organisasi yang berjalan dengan efektif akan menjadikan segala bentuk kendala yang dihadapi perusahaan dalam rangka mencapai kinerja yang maksimal akan dapat disampaikan guna dicari pemecahannya, sehingga perusahaan dapat mencapai kinerja yang maksimal.

\section{PENUTUP}

\section{Simpulan}

Berdasarkan hasil penelitian dan pembahasan yang telah disampaikan pada bagian sebelumnya, maka dapat diambil kesimpulan sebagai berikut:

1. Gaya kepemimpinan partisipatif berpengaruh positif dan signifikan terhadap kepuasan kerja karyawan pada KJPP Jimmy Prasetyo \& Rekan. Semakin baik gaya kepemimpinan partisipatif, maka semakin tinggi kepuasan kerja karyawan pada KJPP Jimmy Prasetyo \& Rekan.

2. Komunikasi organisasi berpengaruh positif dan signifikan terhadap kepuasan kerja karyawan pada KJPP Jimmy Prasetyo \& Rekan. Semakin positif komunikasi organisasi, maka semakin tinggi kepuasan kerja karyawan pada KJPP Jimmy Prasetyo \& Rekan.

3. Kepuasan kerja berpengaruh positif dan signifikan terhadap kinerja karyawan pada KJPP Jimmy Prasetyo \& Rekan. Semakin tinggi kepuasan kerja, maka semakin tinggi kinerja karyawan pada KJPP Jimmy Prasetyo \& Rekan.

4. Gaya kepemimpinan partisipatif berpengaruh positif dan signifikan terhadap kinerja karyawan pada KJPP Jimmy Prasetyo \& Rekan. Semakin positif gaya kepemimpinan partisipatif, maka semakin tinggi kinerja karyawan pada KJPP Jimmy Prasetyo \& Rekan.

5. Komunikasi organisasi berpengaruh positif dan signifikan terhadap kinerja karyawan pada KJPP Jimmy Prasetyo \& Rekan. Semakin baik komunikasi organisasi, maka semakin tinggi kinerja karyawan pada KJPP Jimmy Prasetyo \& Rekan.

\section{Implikasi Manajerial}

Berdasarkan temuan penelitian, maka ada beberapa implikasi kebijakan sesuai dengan prioritas yang dapat diberikan sebagai masukan bagi organisasi dalam hal ini KJPP Jimmy Prasetyo \& Rekan, antara lain:

1. Pada gaya kepemimpinan partisipatif khususnya pada indikator asumsi pada karyawan dapat bekerja sama dan bermoral, atasan pada KJPP Jimmy Prasetyo \& 
Rekan perlu semakin meningkatkan kepercayaan terhadap kemampuan yang dimiliki karyawan, sehingga karyawan dapat semakin merasakan kepuasan dan bersedia menunjukkan kinerja yang maksimal. Pimpinan disarankan dapat lebih memberikan keleluasaan bagi karyawan sepenuhnya mengerjakan penilaian meskipun tetap dilakukan review oleh atasan.

2. Pada komunikasi organisasi khususnya pada indikator komunikasi ke atas (upward communication), karyawan pada KJPP Jimmy Prasetyo \& Rekan perlu meningkatkan partisipasi aktif untuk menanyakan kepada atasan mengenai ketidakjelasan pekerjaan, sehingga dapat terhindar dari kesalahan-kesalahan dalam pekerjaan yang dapat menurunkan kinerja KJPP Jimmy Prasetyo \& Rekan. Karyawan disarankan agar tidak segan-segan bertanya kepada atasan mengenai suatu jenis pekerjaan baru yang kurang dipahami kepada atasan.

3. Pada kepuasan kerja khususnya indikator otonomi (autonomy), atasan pada KJPP Jimmy Prasetyo \& Rekan perlu meningkatkan kesempatan bagi karyawan untuk mengemukan ide-ide, sehingga karyawan dapat semakin terpuasan. Tercapainya kepuasan kerja pada karyawan berdampak besar bagi pencapaian target kerja pada KJPP Jimmy Prasetyo \& Rekan. Karyawan yang melaksanakan tugas penilaian di lapangan hendaknya diberi keleluasaan dalam mengambil langkah konkrit yang dirasa lebih efektif dalam penyelesaian penilaian.

4. Pada kinerja karyawan khususnya pada indikator kedisiplinan, KJPP Jimmy Prasetyo \& Rekan perlu meningkatkan kesediaan karyawan untuk patuh terhadap setiap kebijakan perusahaan. Selain itu, KJPP Jimmy Prasetyo \& Rekan perlu meningkatkan pengawasan terhadap kehadiran karyawan dan memberikan sanksi atas keterlambatan dalam kehadiran, seperti halnya dengan adanya potongan uang makan ataupun bonus dari karyawan yang kurang disiplin.

\section{Keterbatasan dalam Penelitian}

Keterbatasan dalam penelitian ini adalah total $\mathrm{R}^{2}$ adalah 0,379 . Hal ini menunjukkan bahwa 37,9\% variabel kinerja karyawan dapat dijelaskan oleh gaya kepemimpinan partisipatif, komunikasi organisasi, dan kepuasan kerja, sedangkan sisanya sebesar $62,1 \%$ dijelaskan oleh variabel lain di luar model penelitian. Artinya, masih banyak variabel lain yang perlu dimasukkan selain gaya kepemimpinan partisipatif, komunikasi organisasi, dan kepuasan kerja, karena kemampuan menjelaskan variabel-variabel ini masih jauh dari sempurna.

\section{DAFTAR PUSTAKA}

Adeogun, S. O.,. Abiona, B. G., Ajayi, T. D., dan Amuludun, W. 2016. Effects of Organizational Communication Styles on Employees Job Performance in OgunOsun River Basin Development Authority (Oorbda), Ogun State, Nigeria. Journal of Humanities, Social Sciences and Creative Arts. Vol. 11. No. 1 \& 2: 52 - 63.

Ali, Mukti., Idris, Adam., dan Kalalinggi, Rita. 2013. Pengaruh Kepuasan Kerja terhadap Kinerja Pegawai pada Badan Ketahanan Pangan dan Pelaksana Penyuluhan Daerah Kota Samarinda. eJournal Administrative Reform. Vol. 1. No. 2: $418-430$. 
Boateng, Owusu W., dan Jeduah, B. A. 2014. Effects of Organizational Communication on Employee Performance: A Case of the Agricultural Development Bank, Tamale. Public Policy and Administration Research. Vol.4. No.6: 67-81.

Chandraningtyas, Iva., Musadieq, M.A., dan Utami, Hamidah Nayati. 2012. Pengaruh Kepuasan Kerja dan Motivasi Kerja terhadap Kinerja Karyawan Melalui Komitmen Organisasional (Studi pada karyawan PT. Kusuma Karya Persada yang Outsourcing di PT. Sasa Inti Probolinggo). Jurnal Profit. Vol. 6 No. 2: 32-43.

Dariyo, Agus. 2004. Psikologi Perkembangan Dewasa Muda. Jakarta: Grasindo.

Junaedi, Deddy., Swasto, Bambang., dan Utami, Hamidah Nayati. 2016. Pengaruh Gaya Kepemimpinan, Keselamatan dan kesehatan kerja, Kepuasan Kerja terhadap Komitmen Organisasional (Studi Pada Karyawan PG. Kebet Baru Malang). Jurnal Profit. Vol. 7. No. 1: 127-136.

Mangkunegara, A.A.A.P. 2007. Evaluasi Kinerja SDM. Bandung: PT. Refika Aditama.

Muhammad, A. 2001. Komunikasi Organisasi. Jakarta: Bumi Aksara.

Munandar, A. S. 2008. Psikologi Industri dan Organisasi. Jakarta: Universitas Indonesia Press.

Robbins, S. O., dan Judge, T. A. 2008. Perilaku Organisasi. Alih Bahasa: Diana Angelica, Ria Cahyani, dan Abdul Rosyid. Jakarta: Salemba Empat.

Setiawan, Andre. 2017. Pengaruh Gaya Kepemimpinan Partisipatif terhadap Kinerja Karyawan melalui Motivasi Kerja dan Kepuasan. Agora. Vol. 5. No. 3: 1-7.

Soegihartono, A. 2012. Pengaruh Kepemimpinan dan Kepuasan Kerja terhadap Kinerja dengan Mediasi Komitmen (di PT Alam Kayu Sakti Semarang). Jurnal Mitra Ekonomi dan Manajemen Bisnis. Vol. 3. No. 1. Hal. 123-139. Semarang: Fakultas Ekonomi Universitas Dian Nuswantoro.

Soelistya, Djoko. 2014. Pengaruh Gaya Kepemimpinan Partisipatif dan Komunikasi terhadap Motivasi Kerja Serta Dampaknya pada Prestasi Kerja Pegawai di Maspion Group Surabaya Jawa Timur. Jurnal Ilmu Ekonomi \& Manajemen. Vol. 1 No.1: 1-10.

Sunarsih, Nenah., dan Helmiatin. 2016. The Influences of Leadership Style and Job Satisfaction on Employee Performance. IOSR Journal of Business and Management (IOSR-JBM). Vol. 18. Issue 7 : 01-06.

Sutrisno, Edi. 2009. Manajemen Sumber Daya Manusia. Jakarta: Prenada Media Group.

Suwardi., dan Utomo, Joko. 2011. Pengaruh Motivasi Kerja, Kepuasan Kerja dan Komitmen Organisasional terhadap Kinerja Pegawai. Jurnal Analisis Manajemen. Vol. 5. No. 1. Hal. 75-86. Kudus: Fakultas Ekonomi Universitas Muria Kudus. 
Triana, Agnes., Utami, Hamidah Nayati., dan Ruhana, Ika. 2016. Pengaruh Komunikasi Organisasi terhadap Knowledge Sharing dan Kinerja Karyawan (Studi pada Karyawan Hotel Gajah Mada Graha Malang). Jurnal Administrasi Bisnis (JAB). Vol. 35 No. 2: 86-93.

Wexley, K. N., dan Yukl, G. A. 2005. Perilaku Organisasi dan Psikologi Personalia. Alih Bahasa: Drs. Muh. Shobaruddin. Jakarta: PT. Rineka Cipta.

Wibowo. 2013. Perilaku dalam Organisasi. Jakarta: Rajawali Press. 